\title{
Heavy metal, nutrient and antioxidant status of selected fruit samples sold in Enugu, Nigeria
}

\author{
Marcellus Unaegbu', Godwill Azeh Engwa ${ }^{1 *}$, Queen Doofan Abaa', Sandra Ogechukwu Aliozo', \\ Eugene Lakem Ayuk², Gloria Amarachukwu Osuji and Emmanuel Ikechukwu Onwurah ${ }^{3}$
}

\begin{abstract}
Background: Heavy metals, which constitute a major public health concern, are known to accumulate in food and fruits during plants growth. Fruits which are readily consumed because of their characteristic sweet taste and potential health benefits stand a major risk of heavy metal intoxication. Hence, this study assessed some fruits commonly sold in Enugu, Nigeria for their nutrients, antioxidant potential and possible contamination with lead, cadmium and Nickel.

Results: All the ten fruits of five species (apple, pineapple, orange, watermelon and banana) analysed contained glucose, sucrose and phosphates. The fruits were generally acidic with $\mathrm{pH}$ ranging from 3.34 to 5.07. South African water melon had the highest pH of 5.07 while the lowest was Nigerian pineapple (3.34). The acidity was generally low, with the highest acid concentration recorded in Nigerian pineapple $(0.54 \%)$ while American apple had the lowest acid concentration of $0.07 \%$. Ascorbic acid was present in all the fruit samples and was highest in oranges and pineapples. All the fruit samples possessed antioxidant activity to scavenge $\mathrm{H}_{2} \mathrm{O}_{2}$ but did not correlated ( $p=0.973$ ) with the ascorbic acid level. Cadmium and lead were non detectable in all the fruit samples but nickel was detectable in seven samples between 0.03 and $0.09 \mathrm{mg} / \mathrm{L}$. The Nickel level of Egyptian orange, Nigerian orange, Nigerian banana and South African water melon were slightly above the $0.07 \mathrm{mg} / \mathrm{L}$ maximum contaminant level of United State Environmental Protection Agency and World Health Organisation.
\end{abstract}

Conclusion: The fruits are safe for consumption and do not constitute a risk of heavy metal intoxication to warrant public health concern.

Keywords: Fruits, Heavy Metals, Nutrients, Antioxidants, Sugars, Acids, Enugu, Nigeria

\section{Background}

Fruits are generally one of the most consumed foods on a daily basis because of their sweet taste. Majority of fruits are generally sweet because of their richness in sugar. The sugar content of fruits varies depending on the type of fruit and the location of cultivation (Forney and Breen 1986). All sweet fruits are rich in fructose, but vary in their amount of glucose, sucrose and sorbital (Murphy and Johnson 2003). Fructose also known as fruit sugar is one of the most abundant sugars found in

\footnotetext{
* Correspondence: engwagodwill@gmail.com

'Biochemistry, Chemical Sciences Department, Godfrey Okoye University,

P.M.B 01014 Thinkers Corner, Enugu, Enugu State, Nigeria

Full list of author information is available at the end of the article
}

fruits. It has the same caloric value as sucrose but is much sweeter in taste (Lee et al. 1970). Because of the richness in sugar, fruits have been of great economic purposes. They are very important raw material for brewery companies as the sugar content is usually extracted in the form of syrup for the production of soft drinks and juices (Ashurst et al. 2005). Apart from their characteristic taste and commercial uses, fruit consumption is highly recommended because of the nutritional (Willett 1994) and health benefits (Liu 2003).

Fruits are rich in nutrients such as carbohydrate, protein, lipids, vitamins, minerals, fiber etc. which have various functional roles in the body (Craig and Beck 1999). 
Carbohydrates, the most abundant nutrient is essential to provide energy for the body while proteins such as pectinesterase aid in digestion and others for growth. Lipids also serve as energy source as well as important constituents of cell membranes (Kalt 2002). Vitamins are essential components of enzymes and important for various metabolic processes (Mozafar 1994). Apart from the organic constituents, inorganic constituents such as phosphates are also of nutritional importance. Phosphate serves as buffer in body fluids for various metabolic processes (Hays and Swenson 1985) and is a constituent of bone, teeth, adenosine triphosphate (ATP) for energy generation, and also involved in the synthesis of phospholipids and phosphoproteins (Soetan et al. 2013). Acids are present in the human body in minute quantities for various functions. Most importantly, they are present in the gastrointestinal tract for digestion and to killing bacteria.

The initiation and progression of certain diseases such as diabetes, cancer, cardiovascular disease, inflammatory diseases etc. (Young and Woodside 2001; Valko et al. 2007) are as a result of oxidative stress (Kohen and Nyska 2002), a condition characterized by excessive generation of reactive oxygen species (ROS) (Winterbourn 2008) beyond the capacity of the natural antioxidant defence system of the body (Kunwar and Priyadarsini 2011). Certain fruits contain various antioxidants including vitamin $C$, vitamin $A$, vitamin $E, \beta$-carotene, polyphenols, flavonoids, etc. which have been reported to provide protection against some of these diseases (Hong et al. 1996; Dragović-Uzelac et al. 2009). These antioxidants can act as free radical scavengers, decompose peroxide, quench singlet and triplet oxygen as well as inhibit some enzymes that may enhance oxidation (Lien et al. 2008). By decreasing the high levels of free radicals generated by metabolism, antioxidants decrease oxidative stress, carcinogenesis and prevent biochemical and physiological injury that can lead to functional impairment or cell death.

Because of the richness in valuable nutrients and potential health benefits, fruits are readily consumed on a daily basis. The high consumption of these fruits may expose humans to heavy metal intoxication. Fruits contamination by heavy metals is a major aspect of health concern (Ibrahim et al. 2006). During plant growth, certain essential minerals for growth and development like magnesium, iron, manganese, zinc, copper, molybdenum and nickel are usually absorbed from the soil (Yang et al. 2003). However, plants can also accumulate other metals such cadmium, chromium, silver, selenium, lead, mercury etc. which do not have any biological importance but rather have harmful effect to the body (Shaw et al. 2004; Duffus 2002). These heavy metals have the potential of causing acute and chronic toxicity by various modes of action in humans (Sharma and Agrawal 2005). Lead can affect the circulatory renal system which is characterized by mild glucosuria, aminoaciduria, and hyperphosphaturia in the kidney (Staudinger and Roth 1998) and may impair the central nervous system (CNS) especially in children (Lidsky and Schneider 2003). In blood, it can inhibit baminolevulinic acid dehydratase (ALA-D) as well as haem synthetase causing the accumulation of ALA-D and free erythrocyteprotoporphyrin (FEP) respectively which at higher levels may eventually lead to anaemia (Lockitch 1993). Cadmium, another heavy metal of concern is mostly responsible for kidney dysfunction which is characterized by the presence of proteins in urine such as $\alpha_{2}, \beta_{2}$ and $\gamma$-globulin (Godt et al. 2006). Long term accumulation of cadmium may lead to cancer since it is a carcinogenic element (Rubio et al. 2006). However, nickel which is an essential trace element in several animal species, plants and prokaryotic organisms is thought to undergo redox metabolism generating the trivalent form thus forming reactive oxygen species (ROS) (Wang et al. 1993). Also, in experimental animals, nickel has been shown to induce cancer with nickel subsulphide and $\beta$-nickel monosulphide considered the most potent carcinogens (Jarup 2003).

Thus, this study was aimed to characterize certain fruits sold in Enugu Nigeria for their nutrients content and antioxidant potential. However, because of the tendency of possible contamination with heavy metal during growth, the fruits were also assessed for the presence of cadmium, lead ad nickel.

\section{Methods}

Collection of fruit samples and extraction of juice

A total of ten fruits of five species locally known as apple, pineapple, orange, watermelon and banana were obtained for the study. A number of six imported fruits were purchased from a grocery store while four local fruits were purchased from Ogbete market in Enugu Metropolis of Enugu state Nigeria. The fruits were kept in standard refrigerating storage facilities and transported to the Chemistry Laboratory of Godfrey Okoye University, Enugu Nigeria. After the edible fruits parts were ground, the juice was obtained by cold press method and filtered (Trappey et al. 2008). For fruits that do not contain juice such as banana, the grounded pad was diluted with deinoised water.

\section{Nutrient analyses}

The presence of sugars, proteins and phosphates in the fruit samples was detected using Official Methods of Analysis of AOAC International (AOAC, 2005). Acidity was determined according to the relevant AOAC procedure as well. 


\section{Test for sugars}

The presence of sugar was determined using Benedict's reagent. A volume of $3 \mathrm{~mL}$ of the fruit samples was transferred in a test tube followed by $2 \mathrm{ml}$ of Benedict's solution and heated to boiling in a water bath for $5 \mathrm{~min}$. A reddish colour was an indication for the presence of sugar in the fruits.

\section{Test for reducing sugars}

Fehling's test was used to determine the presence of reducing sugar in the fruit. A volume of $3 \mathrm{~mL}$ of the sample was transferred in a test tube followed by $2 \mathrm{~mL}$ of a 1:1 mixture of Fehling's A and Fehling's B. The test tube was heated to boiling in a water bath for $10 \mathrm{~min}$ and the presence of reducing sugar was confirmed by the appearance of a brown precipitation.

\section{Test for phosphates}

Into separate test tubes was transferred $3 \mathrm{ml}$ each of the fruit samples. A volume of $2 \mathrm{~mL}$ of ammonium molybdate followed by $2 \mathrm{~mL}$ of concentrated $\mathrm{HNO}_{3}$ was added. The solution was heated to boiling in a water bath for $10 \mathrm{~min}$ and appearance of canary-yellow precipitate confirmed the presence of phosphate ions in the fruits.

\section{Test for proteins (Biuret test)}

Biuret's reagent forms purple coloured cupric ion complexes with peptide bonds in an alkaline medium. A volume of $3 \mathrm{~mL}$ of each fruit juice extract was transferred into separate test tubes and $3 \mathrm{ml}$ of Biuret's reagent was added to each sample. The presence of a purple colouration indicated the presence of proteins in the fruits.

\section{Determination of acid concentration}

The concentration of the acid was determined by titrating the sample against with a standard $\mathrm{NAOH}$ solution. A volume of $10 \mathrm{~mL}$ of the prepared sample was added in a beaker followed by 2 drops of $1 \%$ phenolphthalein. A volume of $1 \mathrm{~mL}$ of $0.1 \mathrm{M} \mathrm{NAOH}$ filled in a $25 \mathrm{~mL}$ burette was titrated into the beaker containing the fruit sample. Small amount of $\mathrm{NAOH}$ was further titrated until the end point was attained, marked by a colour changed from colourless to pink. The total volume of sodium hydroxide consumed was used to determine the acid concentration.

\section{Determination of $\mathrm{pH}$}

The $\mathrm{pH}$ was read using a $\mathrm{pH}$ meter. The electrode was put into small quantities of each sample just enough to cover the bulb of the electrode. The electrode was left in the sample until a stable reading was obtained.

\section{Determination of ascorbic acid concentration}

It was done by using iodometric titration method (Dumbravă et al. 2011). A volume of $50.00 \mathrm{~mL}$ of fruit juice extract was put in a $125 \mathrm{~mL}$ Erlenmeyer flask. About 10 drops of starch indicator was added to the sample. The prepared iodine solution was titrated against the sample until the endpoint was reached (the first sign of blue color that remains after at least $20 \mathrm{~s}$ of swirling). The final volume obtained at the end point was recorded. The same procedure was done for standard ascorbic acid. The titration was repeated and the average titre value was taken. The concentration of ascorbic acid was calculated as shown below;

$$
\frac{\text { Iodine }_{1}}{\text { Vitamin } C_{1}}=\frac{\text { Iodine }_{2}}{\text { Vitamin } C_{2}}
$$

Where; Iodine ${ }_{1}$ : average volume of iodine $(\mathrm{mL})$ needed to titrate the ascorbic standard solution, Iodine ${ }_{2}$ : average volume of iodine $(\mathrm{mL})$ needed to titrate fruit sample solution, Vitamin $\mathrm{C}_{1}$ : amount of standard ascorbic $(\mathrm{mg})$, Vitamin $\mathrm{C}_{2}$ : amount of fruit sample (mg).

\section{Determination of Hydrogen Peroxide $\left(\mathrm{H}_{2} \mathrm{O}_{2}\right)$ Scavenging Activity}

Scavenging activity of the fruit extract was estimated using the method of Ruch et al. (1989). A volume of 4 $\mathrm{mL}$ of the fruit juice extract was mixed with $0.6 \mathrm{~mL}$ of $4 \mathrm{mM} \mathrm{H} \mathrm{H}_{2} \mathrm{O}_{2}$ solution prepared in phosphate buffer (0.1 M p H 7.4) and incubated for $10 \mathrm{~min}$. The absorbance of the solution was taken at $230 \mathrm{~nm}$ against blank solution containing the plant extract without $\mathrm{H}_{2} \mathrm{O}_{2}$. The amount of hydrogen peroxide radical inhibited by the fruit was calculated using the following equation:

$$
\begin{aligned}
& \mathrm{H}_{2} \mathrm{O}_{2} \text { radical scavenging activity } \\
& \quad=\left\{\left(\mathrm{Abs}_{\text {control }}-\mathrm{Abs}_{\text {sample }}\right) /\left(\mathrm{Abs}_{\text {control }}\right)\right\} \times 100
\end{aligned}
$$

Where; Abs control is the absorbance of $\mathrm{H}_{2} \mathrm{O}_{2}$ radical + solvent; $\mathrm{Abs}_{\text {sample }}$ is the absorbance of $\mathrm{H}_{2} \mathrm{O}_{2}$ radical + fruit sample.

\section{Determination of heavy metals in fruits Sample preparation}

Before the samples were analysed for heavy metals, they were digested according to the method of Wallace (2001). A volume of $10 \mathrm{~mL}$ of $69 \%$ concentrated $\mathrm{HNO}_{3}$ was added to $25 \mathrm{~mL}$ of the sample and the mixture was evaporated on a hot plate in a fume cupboard until brown fumes disappear leaving white fumes. A volume of $50 \mathrm{~mL}$ of distilled water was added to the solution and concentrated by evaporation on a hot plate to $25 \mathrm{~mL}$. A volume of $25 \mathrm{~mL}$ of distilled water was added to the concentrated solution to make up the volume to $50 \mathrm{~mL}$. The solution was then filtered and kept for Flame Atomic Absorption Spectrophotometer (FAAS) analysis using 210GVP Atomic Absorption Spectrophotometer by Buck Scientific Inc., East Norwalk, USA. 


\section{Preparation of metal ion solution and ASS analysis}

The preparation of metal ion solution for the FAAS analysis was done using the calibration plot method described in the British Pharmacopoeia (2005). A $1000 \mathrm{ppm}$ stock standard solution of the metal ion was prepared by dividing the molar mass of the compound containing the element by the molar mass of the element. The weight obtained was considered to be equivalent to $1.0 \mathrm{~g}$ of the metal ion. A corresponding volume of fruit solution (equivalent to $1.0 \mathrm{~g}$ of the metal) was dissolved in $1000 \mathrm{ml}$ to give $1000 \mathrm{ppm}$. A working solution of $100 \mathrm{ppm}$ was prepared from the stock solution of the fruit and absorbance of these solutions was obtained using the AAS at 228.9, 283.3 and $341.5 \mathrm{~nm}$ for cadmium, lead and nickel respectively. The analysis for each sample was done in triplicates and the standard deviation was used to determine the precision. The limit of detection for each element was derived from the standard deviation and calculated based on the blank measurement. Deionised water was used as reagent blank for control. A calibration curve was plotted from a minimum of three standards and the concentration of the metals was derived from the regression equation. The calibration curve was derived from the standard solution at five points ranging in concentrations from 0.5 to $10 \mathrm{mg} / \mathrm{dl}$.

\section{Statistical analysis}

The data obtained was analyzed using statistical package for social sciences (SPSS) version 16.0 and presented as figures. Pearson correlation was applied to evaluate the relationship between ascorbic acid level and hydrogen peroxide scavenging activity. The acceptance level of significance was $P \leq 0.05$.

\section{Results}

Fruits studied and countries of their origin are summarized in Table 1. Qualitative analysis showed the

Table 1 Fruits studied and countries of origin

\begin{tabular}{llll}
\hline Sample ID & Fruit & Scientific name & Source \\
\hline A & Apple & Malus domestica & USA \\
B & Apple & Malus domestica & South Africa \\
C & pineapple & Ananas comosus & ISU \\
D & Orange & Citrus sinensis & Egypt \\
E & Watermelon & Citrullus lanatus & South Africa \\
F & Banana & Musa acuminata & South Africa \\
G & Pineapple & Ananas comosus & Nigeria \\
H & Banana & Musa acuminata & Nigeria \\
I & Orange & Citrus sinensis & Nigeria \\
J & Watermelon & Citrullus lanatus & Nigeria \\
\hline
\end{tabular}

Legend: ISU implies Imported but Source Unknown presence of glucose, sucrose and phosphate in all the fruit samples. Phosphate was abundantly present in American apple and moderately present in South African apple and Egyptian orange. Protein was present in six samples while it was non detectable or present in very low level in four samples (Table 2). The results of the $\mathrm{pH}$, acidity, ascorbic acid and antioxidant activity are shown in Table 3. The fruits were generally acidic with $\mathrm{pH}$ ranging from 3.34 to 5.07. South African water melon had the highest $\mathrm{pH}$ of 5.07 while the lowest was Nigerian pineapple (3.34). The acidity was detectable in seven samples and generally low, with the lowest acid concentration recorded in American apple (0.07 \%) while Nigerian pineapple had the highest acid concentration of $0.54 \%$. Ascorbic acid was present in all the fruit samples and highest in oranges and pineapples. The highest acid level was in Nigerian orange (199 mg/L) and least in Nigerian water melon $(17 \mathrm{mg} / \mathrm{L})$. Also, all the fruit samples showed antioxidant activity to scavenge $\mathrm{H}_{2} \mathrm{O}_{2}$. The highest activity was observed in America apple $(97 \%)$ while the lowest was in Nigerian water melon (22\%). Pearson correlation showed no association ( $p=0.973)$ between ascorbic acid level and $\mathrm{H}_{2} \mathrm{O}_{2}$ scavenging activity (Table 3 ). The $\mathrm{pH}$, acidity, ascorbic acid and $\mathrm{H}_{2} \mathrm{O}_{2}$ scavenging activity of the various fruit samples is summarized in Fig. 1. Nickel was detectable in seven samples with Egyptian orange, South African water melon and Nigerian banana having the highest concentration of $0.09 \mathrm{mg} / \mathrm{L}$. Cadmium and lead were non detectable in all the fruit samples (Table 4).

\section{Discussion}

Most fruits are generally sweet. This constitutes one of the main reasons why they are readily consumed. In this study, glucose and sucrose were present in all the fruit samples. This confirms the sweet taste of the fruits and

Table 2 Presence of glucose, reducing sugars, phosphates and proteins in fruit samples

\begin{tabular}{llllll}
\hline Sample ID & Fruit & Glucose & Reducing Sugar & Phosphate & Protein \\
\hline A & Apple & + & + & ++ & ND \\
B & Apple & + & + & ++ & ND \\
$\mathrm{C}$ & Pineapple & + & + & + & + \\
$\mathrm{D}$ & Orange & + & + & ++ & + \\
$\mathrm{E}$ & Watermelon & + & + & + & + \\
$\mathrm{F}$ & Banana & + & + & + & $\mathrm{ND}$ \\
$\mathrm{G}$ & Pineapple & + & + & + & + \\
$\mathrm{H}$ & Banana & + & + & + & + \\
$\mathrm{I}$ & Orange & + & + & + & $\mathrm{ND}$ \\
$\mathrm{J}$ & Watermelon & + & + & + & + \\
\hline
\end{tabular}

Legend: + Present; ++ moderately present; +++ abundantly present; - absent; ND signifies non detectable or very low level 
Table 3 pH, acidity, ascorbic acid and antioxidant activity of fruit samples

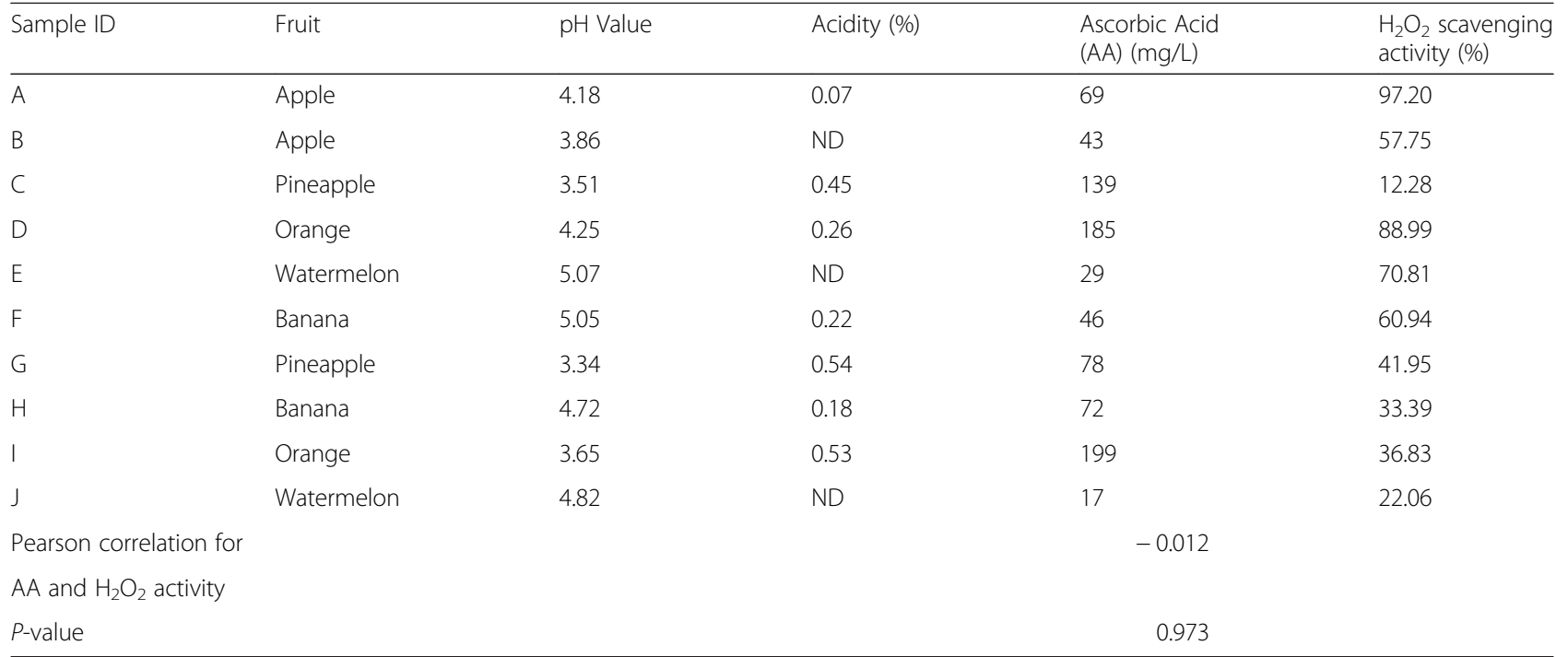

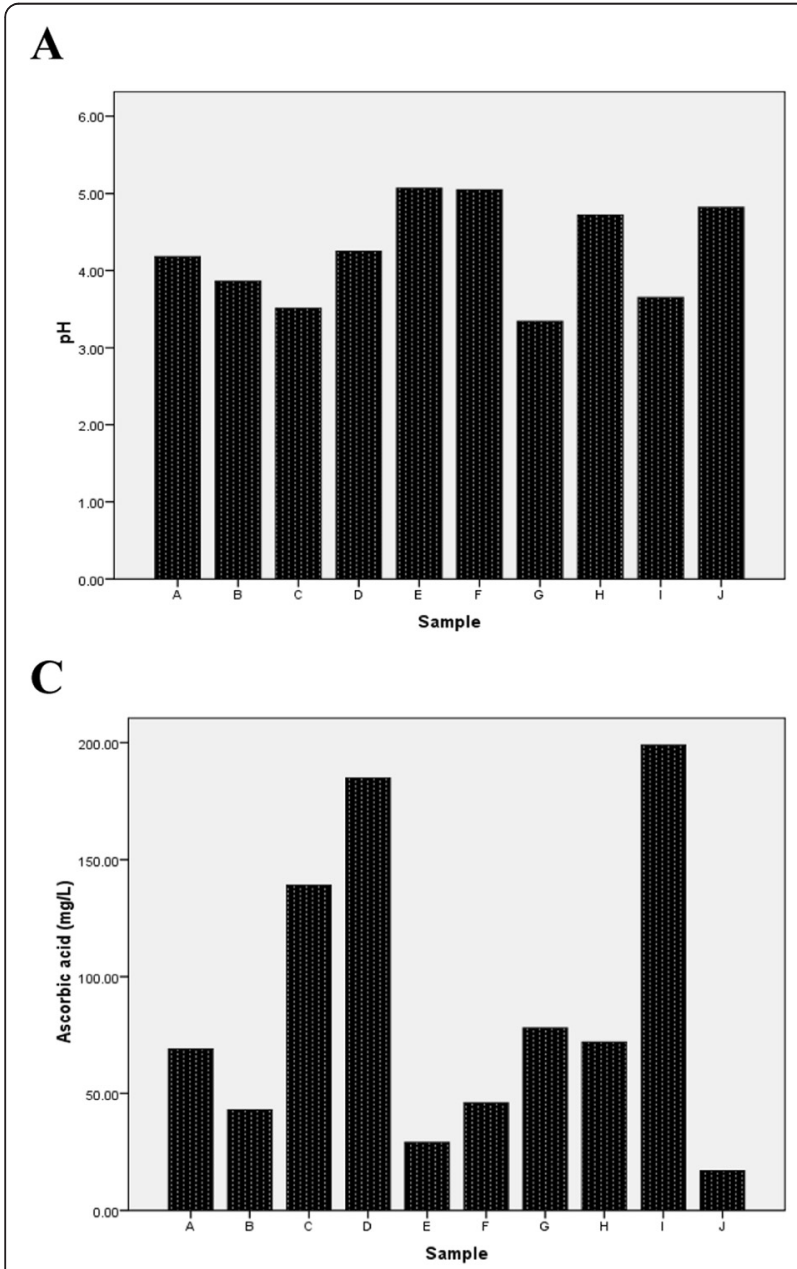

B

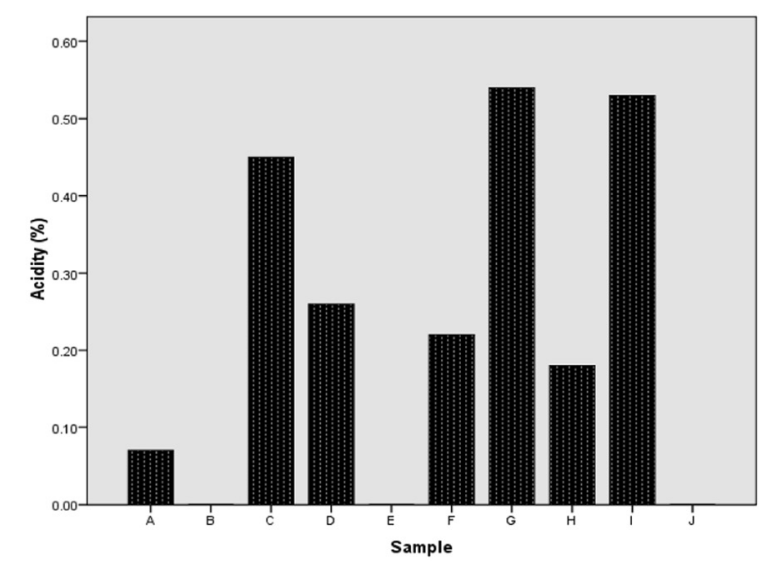

D

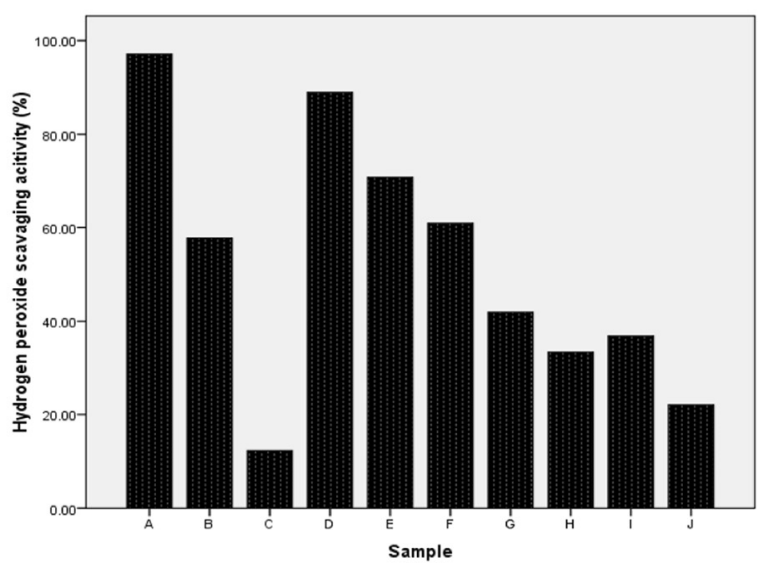

Fig. 1 Shows the level of $\mathrm{pH}(\mathbf{a})$, acidity (b), ascorbic acid (c) and $\mathrm{H}_{2} \mathrm{O}_{2}$ scavenging activity (d) in the various fruit samples 
Table 4 Heavy metals in fruit samples

\begin{tabular}{lllll}
\hline Sample ID & Fruit & $\begin{array}{l}\text { Nickel } \\
(\mathrm{mg} / \mathrm{L})\end{array}$ & $\begin{array}{l}\text { Cadmium } \\
(\mathrm{mg} / \mathrm{L})\end{array}$ & $\begin{array}{l}\text { Lead } \\
(\mathrm{mg} / \mathrm{L})\end{array}$ \\
\hline A & Apple & 0.05 & $\mathrm{ND}$ & $\mathrm{ND}$ \\
B & Apple & $\mathrm{ND}$ & $\mathrm{ND}$ & $\mathrm{ND}$ \\
C & Pineapple & 0.03 & $\mathrm{ND}$ & $\mathrm{ND}$ \\
D & Orange & 0.09 & $\mathrm{ND}$ & $\mathrm{ND}$ \\
E & Watermelon & 0.09 & $\mathrm{ND}$ & $\mathrm{ND}$ \\
F & Banana & $\mathrm{ND}$ & $\mathrm{ND}$ & $\mathrm{ND}$ \\
G & Pineapple & $\mathrm{ND}$ & $\mathrm{ND}$ & $\mathrm{ND}$ \\
H & Banana & 0.09 & $\mathrm{ND}$ & $\mathrm{ND}$ \\
I & Orange & 0.08 & $\mathrm{ND}$ & $\mathrm{ND}$ \\
J & Watermelon & 0.04 & $\mathrm{ND}$ & $\mathrm{ND}$ \\
WHO (mg/L) & & & & 0.07 \\
USEPA (mg/kg/day) & & & & 0.07 \\
\hline
\end{tabular}

their usefulness in the production of soft drinks which has also being shown to be rich in sugar (Engwa et al. 2015). Phosphates are present in all cells of the body especially in cell membrane and body fluids. They are constituent of nucleic acids, teeth and bones and energy storage in the form of ATP. Their deficiencies have been related to poor growth and development (Penido and Alon 2012; Panich and Poolthong 2009). In this study, phosphate was present in all the fruit samples. Phosphates have shown to be readily obtained from dietary sources such as fruits and vegetables (Besford 1979). This provides an added advantaged in consuming these fruits for various health benefits.

In general, fruits with a $\mathrm{pH}$ below 5 have been known to trigger dental erosion effects particularly citrus fruits (Larsen and Nyvad 1999). All the fruits analyzed where acidic in nature with $\mathrm{pH}$ below 5 and as low as 3 for oranges and pineapples. However, the acid concentration was very low less than $1 \%$. This may suggest that the fruit acidity is not a major risk factor for tooth erosion. Hence, their consumption may rely on the health benefits attributed to them rather than the likelihood of causing teeth erosion.

Dietary substances such as vitamins C, E, A, polyphenols etc., known to scavenge free radicals thereby removing them from the body are of importance to supplement the natural antioxidant defence system in oxidative stress conditions (Seifried et al. 2007). In this study, all the fruits possess antioxidant activity as were found to scavenge $\mathrm{H}_{2} \mathrm{O}_{2}$, with American apple showing the greatest activity while Nigerian watermelon showed the lowest activity. The antioxidant activity varied among the various food type and location (Carlsen, et al. 2010). One of the main substances known to contribute to the antioxidant activity of fruits is ascorbic acid (Kalt et al. 1999). Ascorbic acid or vitamin C have being shown to eliminate several ROS, hence, the ascorbic acid content of the fruits was quantified. All the fruits were shown to contain ascorbic acid with pineapple and oranges having the highest amounts. The quantity of ascorbic acid varied among the various fruits. Previous studies have also shown the content of ascorbic acids to vary in different fruits (Szeto et al. 2002). Apart from the antioxidant activity, ascorbic acid has been known to have other important functions in the body. Ascorbic acid keeps $\alpha$-tocopherol, a membrane bound antioxidant in its reduced state thereby enhancing its antioxidant activity (Arrigoni and DeTullio 2000). Also, ascorbic acid acts as a cofactor of some enzymes to maintain their activity and a substrate for oxalate and tartrate biosynthesis (Benzie 1999). More so, when the ascorbic acid content was evaluated for association with the antioxidant activity, the result showed no correlation $(p>0.05)$ suggesting that the antioxidant activity is not dependent on the ascorbic acid level. This is in contrast to the findings of other previous studies which showed a correlation between ascorbic acid level in fruits and their antioxidant activity (Benzie et al. 2009; Dumbravă et al. 2012). Therefore, other antioxidants such as vitamins and polyphenols present in fruits other than ascorbic acid which were not quantified may also have contributed to antioxidant activity.

Heavy metal analysis showed the absence of cadmium and lead in all the fruit samples as were non detectable. In contrast, seven samples contained nickel in varying amounts with Egyptian Orange, South African watermelon and Nigerian banana containing the highest amounts. This confirms the findings of previous studies which have shown nickel to be present in fruits and vegetables (Sobukola et al. 2010; Divrikli et al. 2006). Nickel is one of a few heavy metals whose state remains contradictory to whether they are useful or harmful to the body. Though they have been considered to be essential in animals, microorganisms and plants, they have also being noted to have delirious effects to man. Nickel is known to cause liver, kidney, spleen, brain and tissue damage on acute exposure and it has been reported to react with iron found in haemoglobin which helps in oxygen transport (Divrikli et al. 2006). Out of the seven samples, four fruits contained nickel above the maximum contaminant level of United State Environmental Protection Agency (USEPA 2011) and World Health Organisation (WHO 2011) of $0.07 \mathrm{mg} / \mathrm{L}$. This includes Egyptian orange, Nigerian orange, Nigeria banana and South Africa watermelon with a maximum concentration of $0.09 \mathrm{mg} / \mathrm{L}$. Though the level of nickel in these fruits are slightly above the USEPA and WHO limits, they are not significantly different to pose health concern. A previous study by Orisakwe and colleagues have also shown the presence of nickel and other heavy metals in fruits sold in Owerri, South Eastern Nigeria (Orisakwe et al. 2012). 


\section{Conclusion}

In addition to the presence of sugar which gives fruit its sweet taste, all the fruits were rich in phosphates, ascorbic acid and of low $\mathrm{pH}$ which are beneficial to the body. More so, their capacity to scavenge free radical could be of major health importance in oxidative stress conditions and diseases. Though lead and cadmium, the most toxicity heavy metals were absent in the fruits, nickel which does not constitute a major health concern was present in some fruits. Thus, the fruits are safe for consumption and do not pose any risk of public health concern.

\begin{abstract}
Abbreviations
AAS, Atomic Absorption Spectrophotometer; ALA-D, b-aminolevulinic acid dehydratase; CNS, central nervous system; FEP, erythrocyteprotoporphyrin; ROS, reactive oxygen species; SPSS, statistical package for social sciences; USEPA, United State Environmental Protection Agency; WHO, World Health Organisation
\end{abstract}

\section{Acknowledgements}

We are grateful to the management of Godfrey Okoye University for providing research materials and laboratory space for this project. We equally thank the Vice Chancellor, Rev. Fr. Prof. Christian Anieke for financial assistance and the staff of Chemical Sciences Department for their technical assistance.

\section{Authors' contributions}

GAE, MU and EIO designed the study. GAE, QDA, SOA, GAO and ELA conducted the experiment under the supervision of EIO. GAE and ELA performed the data and statistical analysis. GAE, QDA, SOA and MU drafted the manuscript. All authors read and approved the final manuscript.

\section{Competing interests}

The authors declare they have no competing interests.

\section{Author details}

'Biochemistry, Chemical Sciences Department, Godfrey Okoye University, P.M.B 01014 Thinkers Corner, Enugu, Enugu State, Nigeria. ${ }^{2}$ Industrial Chemistry, Chemical Sciences Department, Godfrey Okoye University, P.M.B 01014 Thinkers Corner, Enugu, Enugu State, Nigeria. ${ }^{3}$ Environmental Biotechnology and Toxicology Unit, Department of Biochemistry, University of Nigeria, Nsukka, Enugu State, Nigeria.

Received: 4 April 2016 Accepted: 20 July 2016

Published online: 28 July 2016

\section{References}

AOAC. Official methods of analysis of AOAC international. 18th ed. Gaithersburg, MD, USA: AOAC International; 2005.

Arrigoni O, DeTullio MC. The role of ascorbic acid in cell metabolism: between gene-directed functions and unpredictable chemical reactions. J Plant Physiol. 2000;157:481-8.

Ashurst PR (Ed). Chemistry and Technology of Soft Drinks and Fruit Juices. 2nd edition, Blackwell Publishing Ltd, 9600 Garsington Road, Oxford OX4 2DQ, UK, 2005

Benzie EJ, Zalewska-Korona M, Kalbarczyk J. Antioxidant capacity, ascorbic acid and phenolics content inwild edible fruits. J Fruit Ornamental Plant Res. 2009;17(2):115-20.

Benzie IF. Prospective functional markers for defining optimal nutritional status: vitamin C. Proc Nutri Soc. 1999;58:1-8.

Besford RT. Uptake and distribution of phosphorus in tomato plants. Plant Soil. 1979;51(3):331-40.

Pharmacopoeia B. Atomic spectrophotometry: emission and absorption. CD: Appendix IID; 2005

Carlsen MH, et al. The total antioxidant content of more than 3100 foods, beverages, spices, herbs and supplements used worldwide. Nutri J. 2010;9(3):1-11.

Craig W, Beck L. Phytochemicals: health protective effects. Can J Diet Pract Res. 1999;60:78-84
Divrikli U, Horzum N, Soylak M, Elci L. Trace heavy metal contents of some spices and herbal plants from western Anatolia. Turkey Int J Food Sci Technol. 2006;41:712-6.

Dragović-Uzelac V, Bursać Kovačević D, Levaj B, Pedisić S, Mezak M, Tomljenović A Polyphenols and antioxidant capacity in fruits and vegetables common in the Croatian Diet. Agric Conspec Sci. 2009;74(3):175-9.

Duffus JH. Heavy metal - a meaningless term? Pure Appl Chem. 2002;74:793-807.

Dumbravă D, Moldovan C, Raba D, Popa M. Comparative analysis of vitamin C content and antioxidant activity of some fruits extracts. J Agroalimentary Processes Technol. 2012;18(3):223-8.

Dumbravă DG, Hădărugă NG, Moldovan C, Raba DN, Popa MV, Rădoi B. Antioxidant activity of some fresh vegetables and fruits juices. J Agroalimentary Processes Technol. 2011;17(2):163-8.

Engwa AG, Ihekwoaba CJ, Ilo US, Unaegbu M, Ayuk LE, Osuji AG. Determination of some soft drink constituents and contamination by some heavy metals in Nigeria. Toxicol Rep. 2015;2:384-90.

Forney CF, Breen PJ. Sugar content and uptake in the strawberry fruit. J Am Soc Hortic Sci. 1986;111(2):241-7.

Godt J, Scheidig F, Grosse-Siestrup C, Esche V, Brandenburg P, Reich A, Groneberg DA. The toxicity of cadmium and resulting hazards for human health. J Occup Med Toxicol. 2006;1:22-30.

Hays WW, Swenson MJ. Minerals and Bones. Dukes' Physiology of Domestic Animals, 1985; 10: 449-466

Hong W, Guohua C, Ronald LP. Total antioxidant capacity of fruits. J Agric Food Chem. 1996:44:701-5.

Ibrahim D, Froberg B, Wolf A, Rusyniak DE. Heavy metal poisoning: clinical presentations and pathophysiology. Clin Lab Med. 2006;26:67-97.

Jarup L. Hazards of heavy metals contamination. Bri Med Bull. 2003;68:167-82.

Kalt W, Forney CF, Martin A, Prior RL. Antioxidant capacity, vitamin C, phenolics, and anthocyanins after fresh storage of small fruits. J Agric Food Chem. 1999;47:4638-44.

Kalt W. Health functional phytochemicals of fruits. Hort Rev. 2002;27:269-315.

Kohen R, Nyska A. Oxidation of biological systems: oxidative stress phenomena, antioxidants, redox reactions, and methods for their quantication. Toxicol Pathol. 2002;30(6):620-50.

Kunwar A, Priyadarsini Kl. Free radicals, oxidative stress and importance of antioxidants in human health. J Med Applied Sci. 2011;1(2):53-60.

Larsen MJ, Nyvad B. Enamel erosion by some soft drinks and orange juices relative to their $\mathrm{pH}$, buffering effect and contents of calcium phosphate. Carr Res. 1999:33:81-7.

Lee CY, Shallenberger RS, Vittum MT. Free sugars in fruits and vegetables. NY Food Life Sci Bull. 1970;1:1-12.

Lidsky TI, Schneider JS. Lead neurotoxicity in children: basic mechanisms and clinical correlates. Brain. 2003;126:5-19.

Lien AP, Hua H, Chuong P. Free Radicals, antioxidants in disease and health. Int J Biomed Sci. 2008;4(2):89-96.

Liu $\mathrm{RH}$. Health benefits of fruit and vegetables are from additive and synergistic combinations of phytochemicals. Am J Clin Nutr. 2003;78:5175-20S.

Lockitch G. Perspectives on lead toxicity. Clin Biochem. 1993;26:371-81.

Mozafar A. Plant vitamins: agronomic, physiological and nutritional aspects. Boca Raton, FL, USA: CRC Press; 1994.

Murphy SP, Johnson RK. The scientific basis of recent US guidance on sugars intake. Am J Clin Nutr. 2003;78:827S-33S.

Orisakwe OE, Nduka JK, Amadi CN, Onyekachi DD, Bede O. Heavy metals health risk assessment for population via consumption of food crops and fruits in Owerri, South Eastern. Nigeria Chem Central J. 2012;6:77-84.

Panich M, Poolthong S. The effect of casein phosphopeptide-amorphous calcium phosphate and a cola soft drink on in vitroenamel hardness. J Am Dental Assoc. 2009;140(4):455-60.

Penido MG, Alon US. Phosphate homeostasis and its role in bone health. Pediatr Nephrol. 2012;27:2039-48.

Rubio C, Hardisson A, Reguera Jl, Revert C, Lafuente MA, Gonzalez-Iglesias T. Cadmium dietary intake in the Canary Islands. Spain Environ Res. 2006;100:123-9.

Ruch RJ, Cheng SJ, Klaunig JE. Prevention of cytotoxicity and inhibition of intercellular communication by antioxidant catechins isolated from chinese green tea. Carcinogen. 1989;10:1003-8.

Seifried $\mathrm{HE}$, Anderson DE, Fishera I, et al. A review of the interaction among dietary antioxidants and reactive oxygen species. J Nut Biochem. 2007;18:567-79.

Sharma RJ, Agrawal M. Biological effects of heavy metals: an overview. J Exp Bot. 2005;26:1-10 
Shaw BP, Sahu SK, Mishra RK. Heavy metal stress in plants. 2nd ed. Berlin: Springer; 2004. p. 84-126.

Sobukola OP, Adeniran OM, Odedairo AA, Kajihausa OE. Heavy metal levels of some fruits and leafy vegetables from selected markets in Lagos. Nigeria Afri J Food Sci. 2010;4(2):389-93.

Soetan KO, Olaiya CO, Oyewole OE. The importance of mineral elements for humans, domesticated animals and plants: A review. Afri J Food Sci. 2013; 4(5):200-22.

Staudinger KC, Roth VS. Occupational lead poisoning. Am Fam Physician. 1998;57:301-13.

Szeto YT, Tomlinson B, Benzie IF. Total antioxidant and ascorbic acid content of fresh fruits and vegetables: implications for dietary planning and food preservation. Bri J Nutri. 2002;87:55-9.

Trappey AF, Johnson CE, Wilson PW. Characterization of juice extraction methods utilizing fresh mayhaw (crataegus opaca hook.) fruit. Int J Fruit Sci. 2008;8(4):318-31

USEPA. Edition of the drinking water standards and health advisories, office of water U.S. Washington, DC: United States Environmental Protection Agency; 2011. 8, 719-726, 731-732.

Valko M, Leibfritz D, Moncola J, Cronin MD. Free radicals and antioxidants in normal physiological functions and human disease (Review). Int J Biochem Cell Biol. 2007:39:44-84.

Wallace HA. Principles and methods of toxicology. 4th ed. Philadelphia: Taylorand Francis Publishing Inc.; 2001. p. 50-5.

Wang X, Yokoi I, Liu J, Mori A. Cobalt(II) and nickel(II) ions as promoters of free radicals in vivo: detected directly using electron spin resonance spectrometry in circulating blood in rats. Arch Biochem Biophys. 1993;306(2):402-6.

WHO. WHO Guidelines for Drinking Water Quality, 4th ed., Geneva: World Health Organization; 2011:72-475

Willett WC. Diet and health: what should we eat? Science. 1994;254:532-7.

Winterbourn CC. Reconciling the chemistry and biology of reactive oxygen species. Nature Chem Biol. 2008;4:278-86.

Yang S, Shu W, Ye W, Lan Z, Wong M. Growth and metal accumulation in vertiva and two sabamia species on lead/zinc mine tailings. Chemoposphere. 2003:52:1593-600.

Young IS, Woodside JV. Antioxidant in health and diseases. J Clin Pathol. 2001:54:176-86

\section{Submit your manuscript to a SpringerOpen ${ }^{\odot}$ journal and benefit from:}

- Convenient online submission

- Rigorous peer review

- Immediate publication on acceptance

- Open access: articles freely available online

- High visibility within the field

- Retaining the copyright to your article

Submit your next manuscript at $\gg$ springeropen.com 